\title{
KOMPARATIVNI PREGLED OBRAZOVANJA ZA ODRŽIVI RAZVOJ I ISTRAŽIVANJE POTREBA ZA STRUČNJACIMA U HRVATSKOJ
}

\author{
Anastasya Raditya-Ležaić, Ana-Maria Boromisa i Sanja Tišma
}

Institut za razvoj i međunarodne odnose Ulica Ljudevita Farkaša Vukotinovića 2, 10000 Zagreb e-mail: anastasya@irmo.hr

\begin{abstract}
Sažetak
Održivi razvoj ima tri dimenzije: ekonomsku, društvenu i okolišnu. Ekonomski rast neophodan je, ali ne i dovoljan za razvoj. Pitanje očuvanja i održivog korištenja okoliša kao poluge razvoja postupno se integrira u razvojne politike. Mecutim, iako su drustvena pitanja, osobito ona vezana uz obrazovanje prepoznata među ključnim odrednicama održivog razvoja, obrazovanje za održivi razvoj u Hrvatskoj ne provodi se sustavno.

U ovom se radu najprije daje pregled razvoja koncepta održivog razvoja. Slijedi prikaz obrazovanja za održivi razvoj, pri čemu se najprije prikazuju preporuke medunarodnih organizacija za obrazovanje za održivi razvoj, a zatim način provedbe u odabranim zemljama na različitim razinama obrazovanja (predskolsko, školsko i visoko). Treći dio rada ocrtava stanje u Hrvatskoj. Uz pregled postojećih programa i dosadašnjih istraživanja donosimo i još neobjavljene rezultate istraživanja o potrebama poslodavaca u Hrvatskoj za stručnjacima za održivi razvoj. Nalazi pokazuju da poslodavci u Hrvatskoj prepoznaju potrebu za zapošljavanjem stručnjaka za održivi razvoj.
\end{abstract}

Ključne riječi: obrazovanje za održivi razvoj, stručnjaci za održivi razvoj, obrazovanje u Hrvatskoj, održivi razvoj

\section{KONCEPT ODRŽIVOG RAZVOJA}

Koncept održivog razvoja na razini UN-a prihvaćen je na konferenciji u Rio de Janeiru 1992. Pri tome se kao održivi razvoj podrazumijeva „razvoj koji zadovoljava potrebe današnjice, a pritom ne ugrožava potrebe budućih generacija“ (UNCED, 1992). Ta je definicija korištena u izvještaju Svjetske komisije za okoliš i razvoj (Brundtland komisija) iz 1987. godine, jednom od pripremnih izvještaja za samita u Riju.

Postupno se identificiraju specifični ciljevi koje treba ostvariti. Milenijskom deklaracijom, koju je prihvatila Opća skupština Ujedinjenih naroda 2000., utvrđeni su Milenijski razvojni ciljevi za razdoblje do 2015. Daljnju političku podršku načelo održivog razvitka dobiva na Svjetskom summitu o održivom razvitku održanom u Johannesburgu, 2002. Konferencija Ujedinjenih naroda o održivom razvoju (engl. United Nations Conference on Sustainable Development - UNCSD) „Rio+20“, održana 2012. godine u Rio de 
Janeiru postavila je sveobuhvatni okvir za održivi razvoj. Među važnijim rezultatima Konferencije odluka je o pokretanju razvoja Ciljeva održivog razvoja (engl. Sustainable Development Goals - SDGs). Ciljeve održivog razvoja je jednoglasno je prihvatilo svih 193 članica UN-a 2015. Nadovezuju se na Milenijske razvojne ciljeve (MDGs) i predstavljati globalnu razvojnu agendu za razdoblje nakon 2015.

Ciljevi održivog razvoja su: (1) iskorjenjivanje siromaštva, (2) iskorjenjivanje gladi, (3) zdravlje i dobrobit, (4) kvalitetno obrazovanje, (5) rodna ravnopravnost, (6) pitka voda i higijenski uvjeti, (7) pristupačna i čista energija, (8) dostojanstven rad i gospodarski rast, (9) industrija, inovacije i infrastruktura, (10) smanjenje nejednakosti, (11) održivi gradovi i održive zajednice, (12) odgovorna potrošnja i proizvodnja, (13) odgovor na klimatske promjene, (14) život ispod vode, (15) život na kopnu, (16) mir i pravda / snažne institucije te (17) partnerstvo za ciljeve.

Podciljevi vezani uz kvalitetno obrazovanje (cilj 4) postavljeni za razdoblje do 2030. su:

- besplatno i kvalitetno osnovno i srednje obrazovanje za sve djevojčice i dječake;

- dostupno jeftino i kvalitetno tehničko, stručno i tercijarno, kao i fakultetsko obrazovanje za sve žene i muškarce;

- znatno povećanje broja mladih i odraslih koji imaju relevantne vještine, između ostalog i tehničke i stručne, za bolju zapošljivost, dobre poslove i poduzetništvo;

- osiguranje rodne jednakosti u obrazovanju te jednak pristup svim razinama obrazovanja i stručnoj obuci za ranjive grupe, uključujući osobe s invaliditetom i djecu u ranjivom položaju;

- osiguranje da svi učenici steknu znanja i vještine potrebne za unaprjeđenje održivog razvoja, putem edukacije za održivi razvoj i održive stilove života, ljudska prava, rodnu ravnopravnost, kao i za promoviranje kulture mira i nenasilja, pripadnosti globalnoj zajednici, poštivanja kulturne raznolikosti i doprinosa kulture održivom razvoju.

Održivi razvoj ne može se postići samo tehnološkim rješenjima, političkom regulativom ili financijskim instrumentima. Potrebno je promijeniti način razmišljanja i djelovanja. Takva promjena zahtjeva kvalitetno obrazovanje i učenje za održivi razvoj na svim razinama i u svim društvenim kontekstima. Obrazovanjem za održivi razvoj nastoji se omogućiti konstruktivno i kreativno rješavanje sadašnjih i budućih globalnih izazova i stvaranje održivih i otpornijih društava. Cilj je obrazovanja za održivi razvoj poboljšanje pristupa kvalitetnom osnovnom obrazovanju, preusmjeravanje nastavnih planova i programa, osposobljavanje i podizanje javne svijesti, kao i pomaganje ljudima da razviju ponašanja, vještine i znanja koja su im potrebna sada i u budućnosti (UNESCO, 2002).

\section{OBRAZOVANJE ZA ODRŽIVI RAZVOJ U SVIJETU}

\subsection{Preporuke i smjernice $U N-a$}

Koncept obrazovanja za održivi razvoj postupno se razvija već od samita u Riju 1992. Agenda 21, jedan od završnih dokumenata samita identificirala je obrazovanje kao bitan alat za postizanje održivog razvoja i istaknula je važnost područja djelovanja vezanog uz 
obrazovanje. Kako bi se obrazovanje za održivi razvoj uvelo u formalne programe obrazovanja, UN je predstavio program Desetljeće obrazovanja za održivi razvoj (engl. Decade of Education for Sustainable Development - DESD) za razdoblje od 2005. do 2014. UNESCO, vodeća agencija za implementaciju DESD-a, navodi da je opći cilj ovog programa: „integrirati načela, vrijednosti i prakse održivog razvoja u sve aspekte obrazovanja i učenja“. Osim toga, DESD je trebao svima omogućiti pristup obrazovanju i mogućnostima za učenjem vrijednosti, ponašanja te načina života, koji su potrebni za održivu budućnost i pozitivnu društvenu promjenu.

Nakon isteka DESD-a UNESCO provodi nastavak tog programa u okviru Globalnog akcijskog programa (GAP) za obrazovanje za održivi razvoj. Globalni akcijski program prepoznaje važnost obrazovanja u postizanju svih 17 ciljeva održivog razvoja. GAP nastoji značajno pridonijeti postizanju ciljeva održivog razvoja kroz dva cilja:

1. preusmjeravanje obrazovanja i učenja tako da svatko ima priliku stjecati znanje, vještine, vrijednosti i stavove koji im omogućavaju da doprinesu održivoj budućnosti, te

2. jačanje obrazovanja i učenja u svim planovima, programima i aktivnostima koji promiču održivi razvoj.

UNESCO je 2017. objavio upute kako koristiti obrazovanje, osobito obrazovanje za održivi razvoj, za ostvarivanje ciljeva održivog razvoja (UNESCO, 2017). U dokumentu se identificiraju potrebne kompetencije, ciljevi i ishodi učenja, teme i aktivnosti potrebne za svaki SDG. Uz kompetencije za svaki SDG identificirane su i ključne, horizontalne kompetencije potrebne za održivost: kompetencija za sustavno razmišljanje, kompetencija za anticipativno razmišljanje, normativna kompetencija, strateška kompetencija, kompetencija za suradnju, kompetencija za strateško razmišljanje, kompetencija za samosvijest (u smislu promišljanja vlastite uloge u lokalnoj zajednici i društvu; kontinuiranog vrednovanja i motiviranja na djelovanje, uvažavajući emocije i želje) te kompetencije za integrirano rješavanje problema.

Ukratko, obrazovanje za održivi razvoj bi, prema svojim proklamiranim ciljevima, trebalo omogućiti svim pojedincima da pridonose postizanju ciljeva održivog razvoja pružajući im potrebna znanja i kompetencije, ne samo da razumiju ove ciljeve, nego da se angažiraju kao informirani građani u ostvarivanju potrebne promjene (UNESCO, 2017).

\subsection{Predškolsko i školsko obrazovanje}

Vrlo je značajno započeti odgoj i obrazovanje za održivi razvoj od ranog djetinjstva. Odgovore na izazove (kao što je bio npr. izlazak iz globalne gospodarske krize) mogu ponuditi samo odgovorni građani koji žive i rade na održiv način. To prepoznaje i UNESCO-vo izvješće „Doprinos ranog i predškolskog odgoja održivom društvu“ koje ističe potrebu za odgojem i obrazovanjem koje može spriječiti daljnje propadanje Zemlje (Pramling Samuelsson, i Kaga, 2008).

Kostović-Vranješ (2015) istaknula je važnost da djeca u ranom djetinjstvu te kasnije kroz odgojno-obrazovni sustav, proučavaju svoje okruženje i uočavaju međuovisnost između ljudskih bića i okoliša, prirodnog i društvenog, te spoznaju odgovornu ulogu 
svakog pojedinca u očuvanju zdravog okoliša kako bi se razvila potreba za očuvanjem prirodnog i društvenog okruženja.

$S$ obzirom na to da je vrlo bitno započeti obrazovanje za održivi razvoj već u predškolskom i školskom odgoju, potrebno je imati nastavnike i učitelje koji imaju znanje o tome. Eilks (2015) navodi da su nastavnici najvažniji čimbenik reforme obrazovanja. Obrazovna reforma i provedba mogu biti uspješne samo ako se uvjerenja nastavnika, njihova stečena znanja i stavovi uzmu u obzir pri provedbi reformi. Edukatori moraju imati kompetencije za uključivanje tema održivog razvoja u proces učenja pri čemu je potrebno voditi računa o osiguranju kanala za pravodoban pristup relevantnim informacijama.

Nažalost, u većini zemalja svijeta ne pridaje se gotovo nikakva pozornost održivom razvoju u predškolskom odgoju i obrazovanju. U mnogim je dijelovima svijeta uloga predškolskog odgoja i obrazovanja u planiranju i provedbi obrazovanja za održivi razvoj podcijenjena (Vrbičić, 2012). Kada bi se obrazovanje za održivi razvoj u predškolskom odgoju i u osnovnoj školi dobro uskladilo s potrebama za obrazovanjem na razini srednje škole, stvorio bi se povezan i usklađen obrazovni proces koji bi se mogao nastaviti na razini visokog obrazovanja.

\subsection{Više razine obrazovanja}

Međunarodni znanstveni programi, svjetske znanstvene akademije i nezavisne mreže znanstvenika počele su promicati znanost o održivosti (engl. sustainability science) početkom 21. stoljeća (Kates i sur., 2001). Znanost o održivosti vrlo je složen koncept za čije je razumijevanje i analizu potrebno kombinirati različite metodologije i discipline. Znanost o održivosti kombinira teorijska, primijenjena i razvojna istraživanja, različite teorije (npr. političke i ekonomske) i pristupe iz brojnih disciplina (poput šumarstva, biologije, ekologije, kemije, filozofije). Nedavno istraživanje koje je provelo Sveučilište u Maastrichtu u Nizozemskoj pokazalo je da različiti dionici koji aktivno stvaraju politike održivosti (poslovna zajednica, nevladine organizacije, međunarodne znanstvene zajednice te druge institucije za visoko obrazovanje) prepoznaju potrebu za stručnjacima $s$ visokom obrazovanjem na području održivog razvoja (Maastricht University, 2018). U posljednje vrijeme sve veći broj sveučilišta diljem svijeta razvija formalni kurikulum koji stavlja u fokus pitanja održivosti. Međutim, ne postoji jedinstveni model ili program edukacije, nego se on prilagođava potrebama, a ovisno o sveučilištu koje ga provodi, aspekt održivosti koji je u fokusu i metode poučavanja mogu biti različiti.

Za ilustraciju, u nastavku prikazani su programi sveučilišta u UK, Švedskoj, Njemačkoj i Austriji za ilustraciju.

Sveučilište SOAS u Londonu nudi i preddiplomski program „Studij razvoja“ i njegov nastavak na diplomskoj razini „Okoliš, politika i razvoj“ (SOAS University of London, 2018). Na preddiplomskoj razini, program nudi multidisciplinarno istraživanje međunarodnog razvoja, siromaštva te gospodarskih i društvenih promjena u ne-zapadnim zemljama. Program pruža studentima priliku da istražuju društvene, političke te gospodarske promjene u zemljama u razvoju. Program „Okoliš, politika i razvoj“ na diplom- 
skoj razini propituje ekološke politike te njihovu povezanost $s$ razvojnim politikama sa socijalno-pravnog stajališta. Predavači su politički ekolozi koji nude kritičku analizu ključnih pitanja vezanih uz vode, šumarstvo, klimatske promjene, ribarstvo, poljoprivrednu proizvodnju, biološku raznolikost i energetiku.

Sveučilište u Uppsali u Švedskoj nudi diplomski program „Održivi razvoj“ koji traje dvije godine. Nakon završetka studija stječe se titula magistra (Uppsala University, 2018). Program je interdisciplinaran, dio se provodi na Sveučilištu u Uppsali, a dio na Švedskom sveučilištu za poljoprivredne znanosti.

Sveučilište u Grazu, u Austriji, nudi diplomski program „Održivi razvoj“. Program je rezultat suradnje više sveučilišta: Sveučilišta u Baselu, Sveučilišta u Grazu, Sveučilišta u Hiroshimi, Sveučilišta u Leipzigu, Sveučilišta u Utrechtu, Cả Foscari Sveučilišta u Veneciji i Sveučilišta TERI u Leipzigu. Ovaj dvogodišnji program usredotočen je na sveobuhvatni pristup problemima održivog razvoja te potrebu i mogućnosti društvenih transformacija (University of Graz, 2018).

Sveučilište Leuphana u Njemačkoj nudi magistarski program „Održivost“. Cilj je programa odgovoriti na pitanja u kojem smjeru te na koji način se može razvijati strategija održivog razvoja u društvenom i ekološkom okviru. Program pruža teorijske, metodološke, organizacijske i komunikacijske vještine koje su ključne za istraživanja u projektima u području održivosti i ekoloških znanosti (Leuphana University of Lüneburg, 2018).

Usprkos razlikama, mogu se identificirati dva osnovna koncepta razvoja sveučilišnih programa, jedan se odnosi na za održivi razvoj (engl. sustainable development) a drugi na znanost o održivosti (engl. sustainability science).

\section{OBRAZOVANJE ZA ODRŽIVI RAZVOJ U HRVATSKOJ}

\subsection{Provedba u predškolskom i školskom sustavu}

Republika Hrvatska potpisala je Agendu 21 o provedbi održivog razvoja. Time se obvezala da će osigurati provedbu u odgojno-obrazovnom sustavu. Deset godine poslije konferencije u Riju održivi razvoj još nije bio zastupljen u školskom obrazovanju u $\mathrm{Hr}$ vatskoj (Jelić-Muck i Pavić-Rogošić, 2002). Strategija održivog razvoja (NN 30/2009) potvrdila je značaj obrazovanja za održivi razvoj, no provedba je ograničena. U nastavku donosimo sažeti prikaz ranije provedenih istraživanja, na temelju kojih je formulirana temeljna pretpostavka našeg istraživanja o potrebi za stručnjacima i obrazovnom programu na diplomskoj razini u Hrvatskoj.

Dosadašnja istraživanja istaknula su važnost obrazovanja održivog razvoja budući da održivi razvoj podiže kvalitetu života sadašnjih i budućih generacija (Borić i sur., 2008). U visokoobrazovnom sustavu, prethodna su istraživanja pokazala da su odgoj i obrazovanje za održivi razvoj i zaštitu okoliša nedovoljno prisutni (Jelić-Muck i Pavić-Rogošić, 2002). Kako bi se utvrdilo u kojoj mjeri sveučilišni profesori, učitelji, odgojitelji i studenti učiteljskog i predškolskog studija razumiju i primjenjuju sadržaje cjeloživotnog učenja za održivi razvoj Borić, Jindra i Škugor provele su istraživanje 2008. (Borić i sur., 2008). 
Istraživanjem je obuhvaćen uzorak od 205 ispitanika uključenih u odgoj i obrazovanje $s$ različitih aspekata: 28 sveučilišnih profesora Učiteljskog fakulteta u Osijeku, 47 učitelja razredne nastave, 44 odgojitelja, 63 studenta 3. godine sveučilišnog petogodišnjeg učiteljskog studija i 23 studenta 3 . godine trogodišnjeg stručnog studija za odgojitelja predškolske djece. Ispitanici su odgovarali na anketu o cjeloživotnom učenju za održivi razvoj koja se sastojala od 15 pitanja zatvorenog tipa. Rezultati istraživanja statistički su obrađeni programskim paketom SPSS 13.0. Rezultati istraživanja pokazuju da većina ispitanika svih skupina smatra da održivi razvoj podiže kvalitetu života sadašnjih i budućih generacija. Trećina studenata učiteljskog i predškolskog studija smatra pojam održivog razvoja kao brigu o okolišu i prirodi, dok većina sveučilišnih profesora smatra da održivi razvoj nije usvojeni obrazac ponašanja, već još uvijek samo aktualna tema. Odgojitelji su najupućeniji u sadržaje cjeloživotnog učenja za održivi razvoj i imaju najviše iskustva u njihovom provođenju.

Većini učitelja i odgojitelja potpuno je jasno koja su očekivanja od njih u području održivog razvoja, dok je to jasno samo trećini sveučilišnih profesora. Usavršavanje sveučilišnih profesora nije sustavno organizirano, a učitelji i odgojitelji se najčešće u tom području usavršavaju putem radionica i projekata. Studenti i sveučilišni profesori smatraju da je najvažniji izvor znanja o sadržajima cjeloživotnog učenja za održivi razvoj nastava. Istraživanje pokazuje da svi ispitanici smatraju kako je najveća zapreka u promicanju cjeloživotnog učenja za održivi razvoj nerazvijena svijest društva.

Drugo istraživanje (Anđić, 2015) provedeno je na uzorku od 740 radnika u 40 osnovnih škola u Republici Hrvatskoj. Ispitanici su uključivali ravnatelje $(\mathrm{N}=33)$, radnike stručno-razvojnih službi $(\mathrm{N}=67)$ i, učitelja predmetne $(\mathrm{N}=389)$ i razredne nastave $(\mathrm{N}=251)$. Cilj istraživanja bilo je utvrditi samoprocjenu ključnih kompetencija (didaktičko-metodičke, opće i predmetne) učitelja osnovnih škola u njihovom dosadašnjem usavršavanju i implementaciji koncepta odgoja i obrazovanja za održivi razvoj u školama. Rezultati su pokazali da oblici usavršavanja koji se nude učiteljima dovoljno ne doprinose razvoju kompetencija. Najveći pozitivan prediktor je samoobrazovanje. Kao prepreke značajnijem sudjelovanju u određenim oblicima usavršavanja koji su ovim istraživanjem identificirani kao pozitivni prediktori kompetencija (radionice, seminari i predavanja, radionice Agencije za odgoj i obrazovanje, županijska stručna vijeća i znanstveni, stručni skupovi i konferencija) financijska su ograničenja škola i učitelja. Zbog tih ograničenja škole ne potiču učitelje na sudjelovanje $\mathrm{u}$ aktivnostima koje razvijaju kompetencije niti na uključivanje $\mathrm{u}$ ostale oblike stručnog usavršavanja u odgoju i obrazovanju za održivi razvoj.

Treće istraživanje (Kostović-Vranješ, 2016) čije rezultate prikazujemo, odnosi se na analizu učiteljskih programa i aktualnih stručnih usavršavanja učitelja. Cilj tog istraživanja bio je utvrditi koliko se budući učitelji mogu osposobiti tijekom inicijalnog obrazovanja i usavršiti tijekom stručnog usavršavanja za realizaciju obrazovanja za održivi razvoj u nastavnoj praksi. Uspoređujući nastavne programe učiteljskih studija svih učiteljskih fakulteta u Republici Hrvatskoj utvrđeno je da je količina nastavnih sadržaja, koji bi bili temelj znanja i kompetencija učitelja za provođenje obrazovanja za održivi razvoj, nedovoljna. Najgori su rezultati u obveznim dijelovima programa. Analizom je utvr- 
đeno da samo Učiteljski fakultet u Rijeci i Učiteljski fakultet Osijeku imaju obvezne predmete Ekologija i Pedagoška ekologija. Ostali fakulteti nude izborne predmete koji mogu poslužiti za osposobljavanje budućih učitelja u provođenju obrazovanja za održivi razvoj. Programi učiteljskih studija ne pružaju mogućnost osposobljavanja studenata za implementaciju obrazovanja za održivi razvoj.

\subsection{Kurikularna reforma}

U okviru kurikularne reforme koju trenutno provodi Ministarstvo znanosti i obrazovanja postoji sedam prijedloga kurikuluma međupredmetnih tema. Jedan od njih je nacionalni kurikulum međupredmetne teme Održivi razvoj (Ministarstvo znanosti i obrazovanja, 2017). Prijedlog je napravljen u prosincu 2017. nakon javne rasprave.

Prema prijedlogu kurikuluma zamišljeno je da se tema održivi razvoj organizira kroz tri domene: povezanost, djelovanje te dobrobit. Povezanost obuhvaća temeljna načela održivosti i međuovisnosti u ekosustavima, djelovanje obuhvaća potrebu aktivnoga širenja i primjene prikladnih znanja i vještina za održivo življenje, a dobrobit obuhvaća prava i odgovornosti u ostvarivanju željenoga cilja: dobrobiti za sve ljude, okoliš i buduće generacije. Sve tri domene raspodijeljene su kroz 5 odgojno-obrazovnih ciklusa u postojećoj strukturi školskog sustava: 1 . ciklus daje se u predškoli te od prvog do drugog razreda osnovne škole, 2. ciklus od trećeg do petog razreda osnovne škole, 3. ciklus od šestog do osmog razreda, 4. ciklus u prvom i drugom razredu četverogodišnjeg srednjoškolskog programa, odnosno samo u prvom razredu trogodišnjeg srednjoškolskog programa, te 5. ciklus u trećem i četvrtom razredu četverogodišnjeg srednjoškolskog programa, odnosno u drugom i trećem razredu trogodišnjeg srednjoškolskog programa.

Preporučuje se provođenje obrazovanja kroz predmete: priroda i društvo, hrvatski jezik, likovna kultura, matematika, informatika, geografija, tehnička kultura, kemija, biologija te kroz izvannastavne i izvanškolske aktivnosti.

\subsection{Provedba u visokoobrazovnom sustavu}

Na hrvatskim sveučilištima razvijaju se programi i pojedini predmeti koji se bave održivim razvojem. Na temelju analize postojećih programa te sveučilišta, veleučilišta i visokih škola koje ih provode mogu se identificirati dvije grupe programa: jedni su pretežno društveno-humanistički, koji se fokusiraju na kreiranje politika za održivi razvoj, a u drugoj grupi su studiji za održivi razvoj koji se fokusiraju na tehnička (inženjerska) rješenja za održivost.

Primjerice, Međimursko veleučilište u Čakovcu nudi preddiplomski stručni studij „Održivi razvoj" - Studij traje tri godine i fokusira se na tehničke aspekte održivog razvoja. Program se izvodi od 2012. i ima tri studijska smjera: održiva gradnja, termotehničko strojarstvo i ekoinženjerstvo (Međimursko veleučilište u Čakovcu, 2018).

Visoka škola međunarodnih odnosa i diplomacije Dag Hammarskjöld pokrenula je u akademskoj godini 2017./2018. novi studijski program „Održivi razvoj i međunarodni odnosi“" na razini preddiplomskog i diplomskog specijalističkog studija. Studij obuhvaća područja politike, zaštite okoliša, razvoja, ekonomije i energetike. Cilj mu je educirati 
stručnjake koji će znati analizirati i provoditi programe održivog razvoja i koji će stečeno znanje moći primijeniti za razvoj konkretnih politika i projekata u Hrvatskoj i inozemstvu (VŠMOD, 2018). Međutim, školarina za ovaj je studij visoka (35.100 kn za jednu akademsku godinu). Na stranici škole kao potencijalni poslodavci za ove stručnjake navedena su diplomatska predstavništva, vlada, ministarstava, javna i privatna poduzeća koja u svome krugu djelovanja imaju i međunarodnu suradnju, predstavništva tvrtki u inozemstvu, društva u Hrvatskoj koja posluju s inozemstvom, razne (društvene i prirodoslovne) znanstvene organizacije te nevladine udruge koje surađuju ili namjeravaju surađivati s inozemstvom.

Iako ne nude cjelokupni program „Održivi razvoj“ kao gore spomenuto veleučilište i visoka škola, nekoliko ustanova visokog obrazovanja u Hrvatskoj nudi mogućnost učenja o održivom razvoju kao izborni predmet.

Sveučilište VERN uvrstilo je predmet „Zaštita okoliša i održivi razvoj" u izborne predmete koji mogu birati svi redovni i izvanredni studenti 3. godine studija Ekonomije poduzetništva (Sveučilište VERN, 2018). Na zagrebačkom Fakultetu elektrotehnike i računarstva, „Okoliš i održivi razvoj“ jedan je od izbornih predmeta preddiplomskog studija, a povezuje ekologiju, okoliš, zaštitu okoliša i gospodarstvo (Fakultet elektrotehnike i računarstva, 2018). Predmet „Održivi razvoj“ jedan je od obaveznih predmeta za studente prve godine preddiplomskog studija Industrijske ekologije na Metalurškom fakultetu Sveučilišta u Zagrebu (ODRAZ, 2018). Na studijima ranog i predškolskog odgoja i obrazovanja, predmet „Odgoj i obrazovanje za održivi razvoj“ počeo je stjecati popularnost. Na Filozofskom fakultetu u Splitu, ovaj je predmet obvezan za sve studente Diplomskog studija ranog i predškolskog odgoja i obrazovanja (Filozofski fakultet u Splitu, 2018).

Predviđa se i uvođenje magistarskog studija s fokusom na tehničke aspekte održivog razvoja. Taj studij rezultat je suradnje Splitskog, Zagrebačkog, Riječkog i Osječkog sveučilišta, a predvodnik je Građevinski fakultet u Splitu (Režić, 2017).

\section{POTREBA ZA STRUČNJACIMA ZA ODRŽIVI RAZVOJ U HRVATSKOJ}

U prethodnim dijelovima rada, utvrđena je potreba za obrazovanjem za održivi razvoj u skladu sa smjernicama UN-a i strateškim dokumentima u Hrvatskoj. Usprkos tome, u Hrvatskoj se još sustavno ne provodi obrazovanje za održivi razvoj, ali postoje inicijative za poboljšanje sustava na predškolskoj, školskoj i srednjoškolskoj razini. U visokom obrazovanju, u skladu sa svjetskim trendovima, pokrenuti su pojedinačni predmeti vezani za održiv razvoj i cjeloviti studiji. U nastavku se prikazuju rezultati istraživanja provedenog među potencijalnim poslodavcima o potrebi za stručnjacima za održivi razvoj.

\subsection{Cilj i metodologija istraživanja}

Istraživanje je za cilj imalo doći do aktualnih saznanja o percepciji potrebe za stručnjacima za održivi razvoj među potencijalnim poslodavcima. Temeljilo se na anketi standarda zanimanja (Ministarstvo rada i mirovinskog sustava, 2016) čija je metodologija 
razvijena u okviru radne skupine koju su činili predstavnici Ministarstva rada i mirovinskog sustava, Ministarstva znanosti, obrazovanja i sporta te Hrvatskog zavoda za zapošljavanje. Anketa je obuhvatila četrdeset pitanja grupiranih u osam kategorija: (i) opći podaci o poslodavcu, (ii) opis radnog mjesta, (iii) opis ključnih poslova, specifičnih znanja i vještina, (iv) osposobljavanje za radno mjesto, (v) ključne kompetencije, (vi) generičke vještine i psihomotoričke sposobnosti, (vii) karakteristike radnog mjesta i viii povratne informacije i komentare).

Metoda provedbe ankete prilagođena je preferencijama ispitanika, koji su mogli izabrati između: (1) online ankete (ispitanik samostalno popunjava online upitnik koristeći računalni program LimeSurvey), (2) CATI metode (educirani anketar telefonski provodi intervju s ispitanikom), (3) F2F metode (educirani anketar provodi intervju s ispitanikom u uredu ispitanika) te (4) PAPI metode (ispitanik samostalno popunjava papirnati upitnik). Podaci i rezultati obrade podataka prikazani su tablično i grafički. Za obradu i prikaz rezultata istraživanja po pojedinim pitanjima koriste se frekvencije i postoci. $U$ nastavku su prikazani rezultati koji se odnose na uzorak, postojeće stručnjake, njihov broj i obrazovanje te percepciju poslodavaca za potrebama za stručnjacima i njihovim vještinama i obrazovanju.

\subsection{Obilježja uzorka}

Istraživanje je obuhvatilo ustanove i poduzetnike sa stalno zaposlenim radnicima, a provedeno je u studenome 2015. u Gradu Zagrebu, Zagrebačkoj županiji te Krapinsko-zagorskoj županiji, u institucijama u kojima, prema procjeni autora, postoje potrebe za stručnjacima za održivi razvoj. Značaj istraživanja potencijalnih poslodavaca u odnosu na ostalo stanovništvo proizlazi iz potrebe za usklađivanjem programa obrazovanja $s$ tržištem rada.

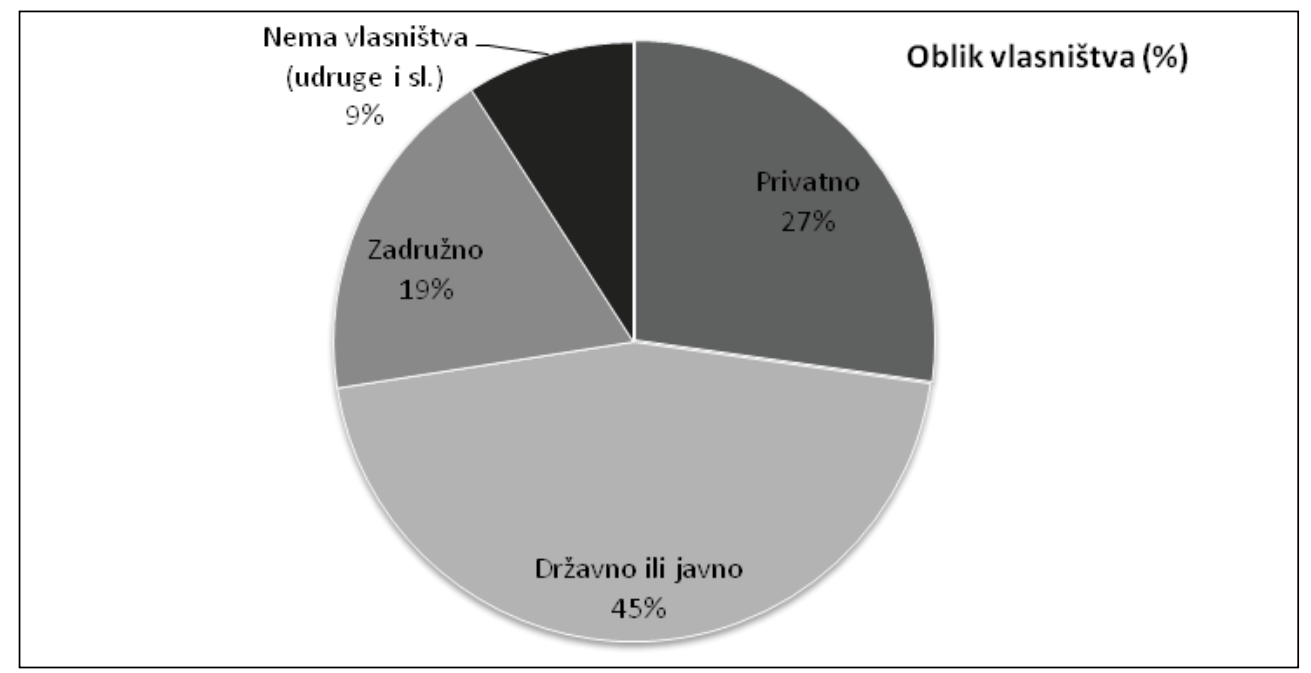

Slika 1. Oblik vlasništva institucija $(N=50)$ 
Time se može podići svijest budućih studenata o važnosti obrazovanja održivog razvoja ako se ispostavi da postoji potražnja za stručnjacima održivog razvoja na tržištu rada. Istraživanje je provedeno na uzorku od pedeset (50) odabranih potencijalnih poslodavaca, uključujući privatna poduzeća (različite veličine; uključujući domaće i strane osnivače), javna poduzeća, diplomatska predstavništva, razvojne agencije, jedinice lokalne i regionalne samouprave (vidjeti Sliku 1).

Anketom je ispitano 50 ispitanika koji, prema procjeni autora, trebaju stručnjake za održivi razvoj. Ispitanik u svakoj organizaciji je osoba koja bi, prema svojoj funkciji u organizaciji, trebala biti najbolje upoznata $s$ radnim zadacima stručnjaka za održivi razvoj. Distribucija uzorka s obzirom na oblik vlasništva institucije prikazana je na Slici 1.

Veličine institucija različite su od onih koje imaju manje od 10 zaposlenika do onih koje imaju više od 100 zaposlenika. Distribucija uzorka s obzirom na ukupan broj zaposlenih prikazana je na Slici 2.

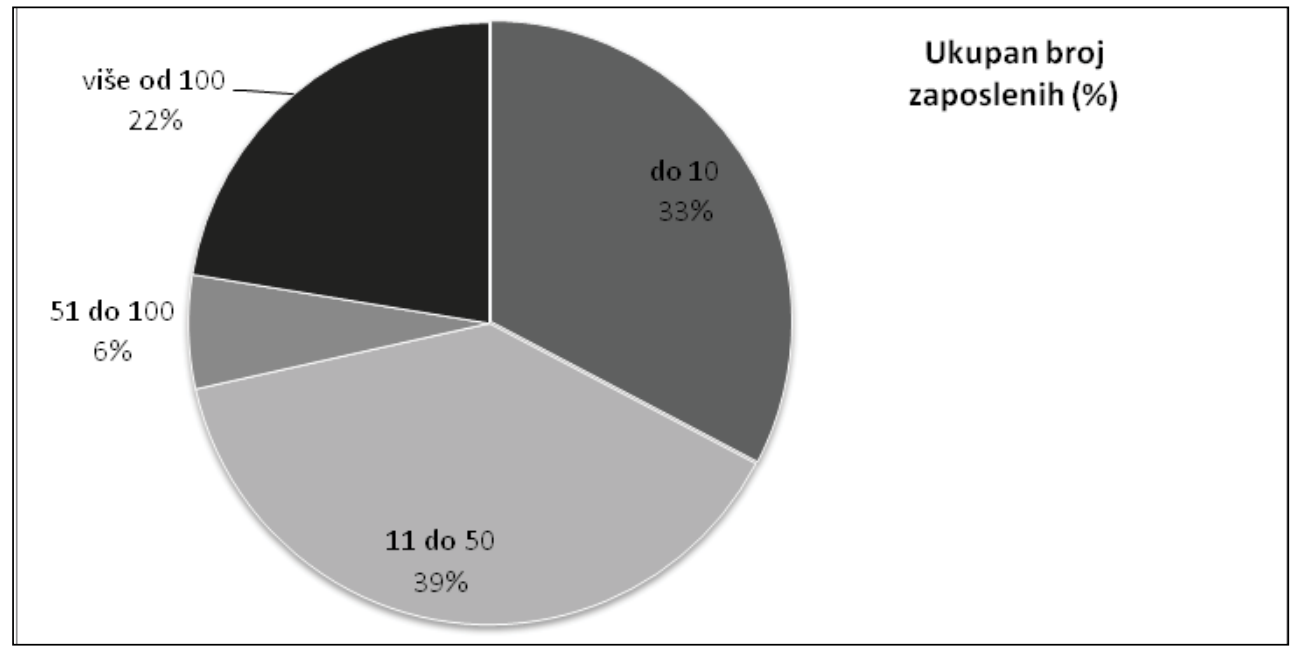

Slika 2. Ukupan broj zaposlenih u instituciji $(N=50)$

\subsection{Potreba za stručnjacima za održivi razvoj}

Većina ispitanika (80\%) izjavila je da imaju potrebu za stručnjakom za održivi razvoj te da već postoji takvo ili slično radno mjesto, a ostatak (20\%) izjavilo je da ne postoji takvo radno mjesto te da nemaju potrebu za takvim radnim mjestom u svojoj organizaciji.

Od onih koji već imaju zaposlenog stručnjaka za održivi razvoj ili sličnog takvog zaposlenika $(\mathrm{N}=40), 60 \%$ zapošljava jednog takvog stručnjaka, dok ostali zapošljavaju više stručnjaka. Distribucija uzorka već zaposlenih stručnjaka za održivi razvoj prikazana je na Slici 4. Nazivi za radno mjesto različiti su ovisno o organizaciji, iako su zadaci i potrebne kompetencije usporedivi. Neki od naziva su: stručni suradnik za održivi razvoj i suradnju, stručnjak za međunarodnu suradnju i održivi razvoj, specijalist zaštite okoliša, stručnjak za učinkovito upravljanje resursima, koordinator za međunarodnu suradnju i održivi razvoj, itd. Potreban broj stručnjaka za održivi razvoj raste s brojem zaposlenih u organizaciji. Međutim, ta veza 
nije jednoznačna, budući da su uzorkom bile obuhvaćene i male organizacije specijalizirane za održivi razvoj (do 10 zaposlenih, a svi s kompetencijama za održivi razvoj).

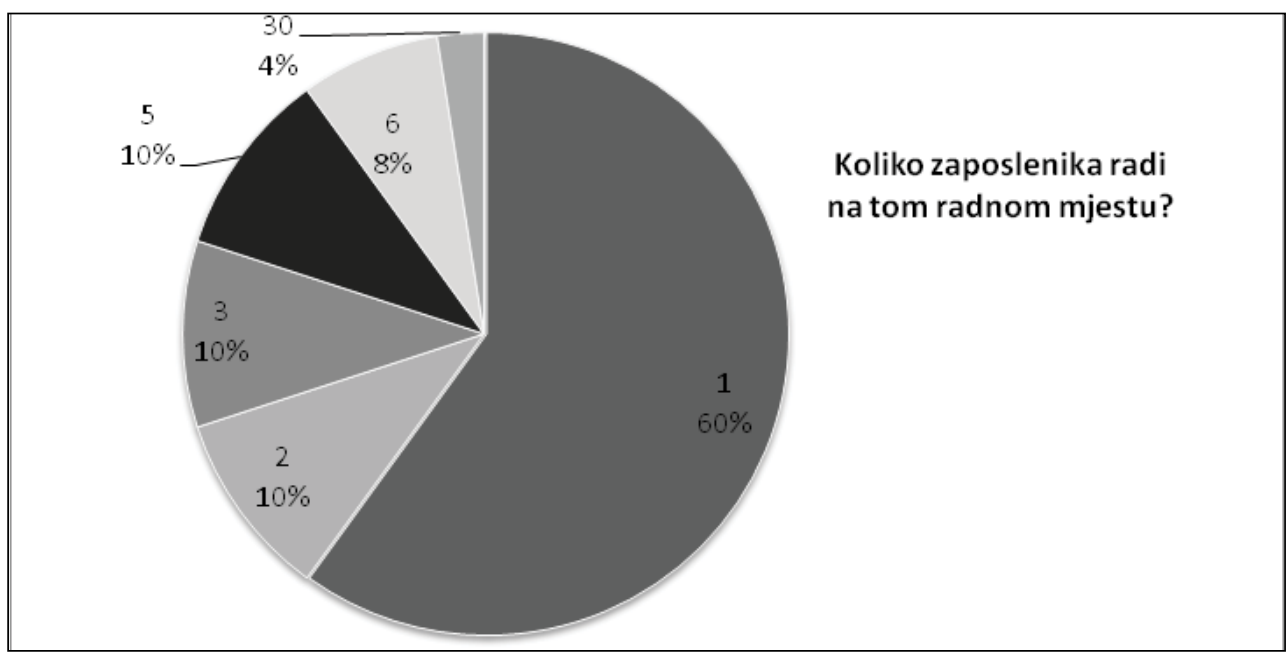

Slika 3. Broj zaposlenih na radnom mjestu stručnjaka za održivi razvoj ili slično $(N=40)$

\subsection{Potrebno obrazovanje za održivi razvoj}

Više od $60 \%$ ispitanika smatra da je za takvo radno mjesto potreban diplomski studij (sveučilišni diplomski studij ili specijalistički diplomski stručni studij - prethodno poznato kao Visoka stručna sprema / VSS) kao minimalno obrazovanje. Malen udio poslodavaca smatra da su preddiplomski studij (prethodno poznati kao Viša stručna sprema / VŠS) i srednjoškolsko i gimnazijsko obrazovanje (SSS) dovoljni. Potrebna razina kvalifikacije prikazana je na Slici 4.

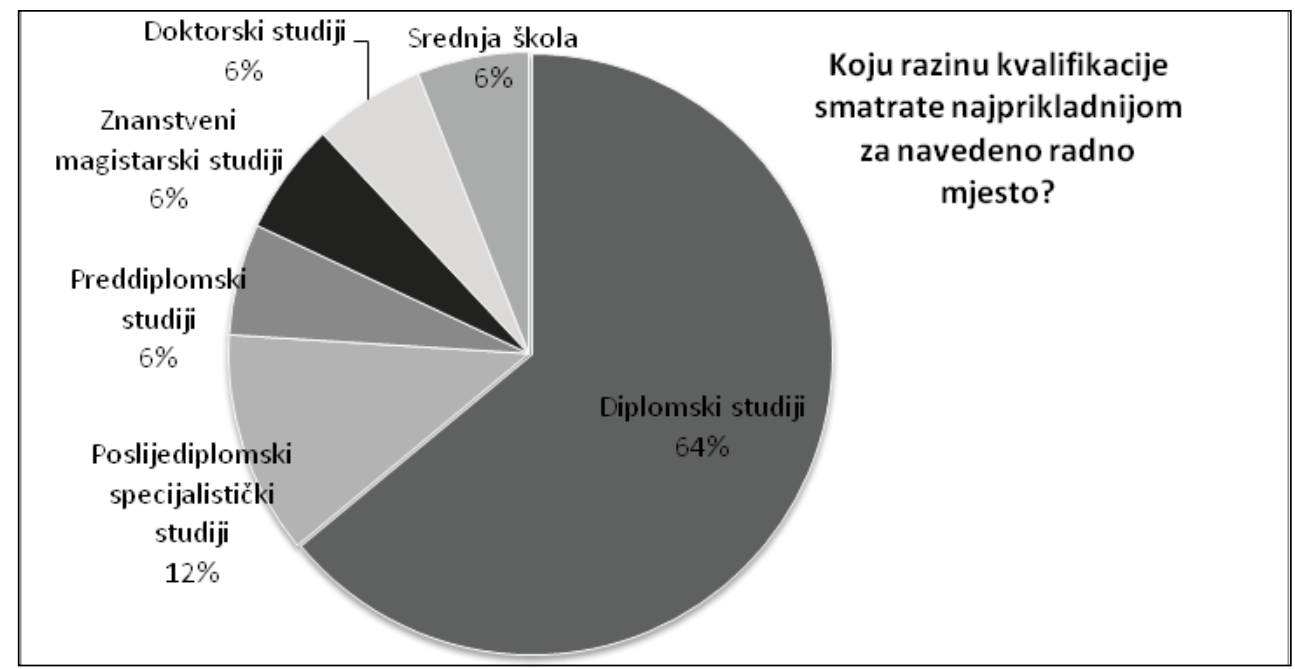

Slika 4. Potrebna razina kvalifikacije za stručnjaka za održivi razvoj (N=50) 
S obzirom na to da održivi razvoj kao posebna struka još ne postoji u Hrvatskoj, kada je obrazovni program u pitanju, više od polovice ispitanika smatra da im je potreban stručnjak koji je završio ekonomski smjer. Završen studij političkih znanosti, diplomacije i međunarodnih odnosa drugi su najpoželjniji stručnjaci. Ostali potrebni obrazovni programi uključuju tehnička i biotehnička usmjerenja, prirodoslovna usmjerenja, pravo, te druga društvena usmjerenja. Distribucija odgovora ispitanika prema potrebnom obrazovanju za radno mjesto stručnjaka za održivi razvoj prikazana je na Slici 5 . Na ovo su pitanje (Molimo navedite obrazovni program koji smatrate najprikladnijim za dotično radno mjesto) ispitanici su mogli dati do tri odgovora.

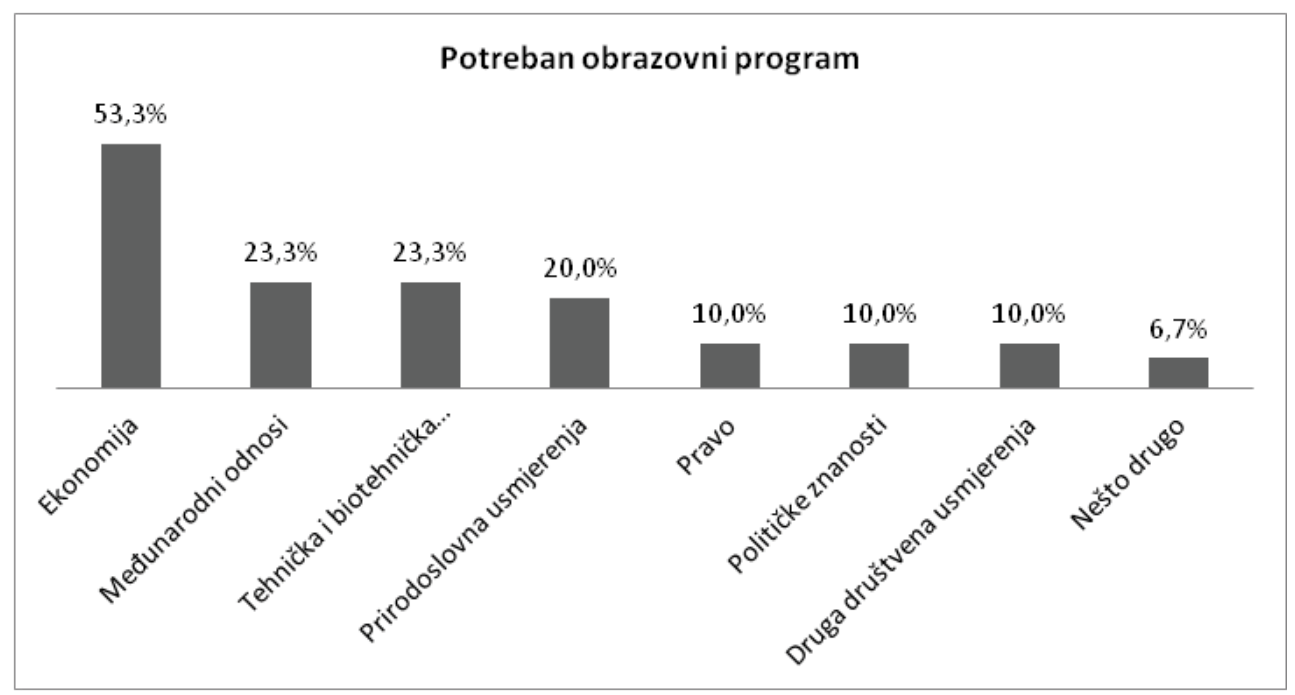

Slika 5. Potreban obrazovni program za stručnjaka za održivi razvoj

\section{ZAKLJUČAK}

Kako bi se visokoobrazovni sustav za održivi razvoj razvijao, potrebno unaprijediti sustav već na školskoj razini, što znači da je potrebno imati nastavnike i učitelje koji to razumiju. Obrazovanje za održivi razvoj u Hrvatskoj se ne provodi sustavno, nego ovisi o mogućnosti učitelja da ga integrira u aktualni nastavni program. Već u školskom sustavu treba se poticati istraživački i problemski pristup održivog razvoja te razvijati kompetencije za održivost na već postojećem sadržaju o primjerice, zaštiti okoliša i prostornom uređenju. Važnost obrazovanja za održivi razvoj prepoznata je u društvu, što dokazuje i postojeći prijedlog za nacionalni kurikulum međupredmetnog održivog razvoja. Taj sadržaj predviđa integrirano obrazovanje u osnovnim i srednjim školama, no početak sustavne primjene i dalje je neizvjestan. U visokoobrazovnom sustavu postoje pojedinačne inicijative za razvoj programa visokog obrazovanja za održivi razvoj kojim bi se educirali stručnjaci za održivi razvoj. Sveučilišta, veleučilišta te visoke škole kreiraju 
cjelokupne preddiplomske i diplomske programe održivog razvoja s različitim fokusima i ciljevima. Predmeti povezani s održivim razvojem također su prisutni kao obavezni ili izborni predmeti na sveučilištima koja ne nude cjelovit program.

Rezultat istraživanja pokazuje da postoji potreba za stručnjacima za održivi razvoj na tržištu rada u Hrvatskoj. Najpoželjniji su stručnjaci oni koji su završili razinu obrazovanja diplomskog studija. Iako nazivi nisu uniformni, takvo radno mjesto već postoji u raznim hrvatskim institucijama i poslovnim subjektima. Postoji samo jedan fakultet koji nudi studijski program za održivi razvoj. Slično kao u Njemačkoj i Nizozemskoj, studij za održivi razvoj u Hrvatskoj treba biti interdisciplinaran te kombinirati ekonomske, politološke, sociološke, tehničke i prirodoslovne teme koje su potrebne na tržištu rada.

\section{LITERATURA}

Anđić, D. (2015). Doprinosi razvoju kompetencija učitelja osnovnih škola u odgoju i obrazovanju za održivi razvoj. Napredak: časopis za pedagogijsku teoriju i praksu, 156(4): 367-383.

Borić, E., Jindra, R. i Škugor, A. (2008). Razumijevanje i primjena sadržaja cjeloživotnog učenja za održivi razvoj. Odgojne znanosti, 10(2): 315-327.

Eilks, I. (2015) Science Education and Education for Sustainable Development - Justifications, Models, Practices and Perspectives, Eurasia Journal of Mathematics. Science \& Technology Education, 11(1): 149-158.

Fakultet elektrotehnike i računarstva, Sveučilište u Zagrebu. (2018). Okoliš i održivi razvoj. URL: https://www.fer.unizg.hr/predmet/eor (26.02.2018.)

Filozofski fakultet u Splitu (2018). Odgoj i obrazovanje za održivi razvoj. URL: https:// www.ffst.unist.hr/odsjeci/predskolski/diplomski_studij?@=212u1 (26.02.2018.)

Jelić-Muck, V. i Pavić-Rogošić, L. (2002). Pregled i ocjena napretka provedbe Agende 21 u Hrvatskoj. Radni materijal za raspravu. Zagreb: ODRAZ - Održivi razvoj zajednice. URL: http://www.odraz.hr/media/21885/agenda21.pdf (24.01.2018.)

Kates, R. W., Clark, W. C., Corell, R., Hall, J. M., Jaeger, C. C., Lowe, I., McCarthy, J. J., Schellnhuber, H. J., Bolin, B., Dickson, N. M., Faucheux, S., Gallopin, G. C., Grübler, A., Huntley, B., Jäger, J., Jodha, N. S., Kasperson, R. E., Mabogunje, A., Matson, P., Mooney, H., Moore, B., O’Riordan, T. i Svedin, U. (2001). Sustainability Science. Science, 292(5517): 641-642.

Kostović-Vranješ, V. (2015). Baština - polazište za promicanje odgoja i obrazovanja za održivi razvoj. Školski vjesnik: časopis za pedagogijsku teoriju i praksu, 64(3): 439-452.

Leuphana University of Lüneburg (2018). Sustainability Science. URL: https://www. leuphana.de/en/graduate-school/master/course-offerings/sustainability-science. html (30.01.2018.)

Maastricht University (2018). Sustainability Science and Policy Master. URL: https:// www.maastrichtuniversity.nl/education/master/master-science-sustainability-science-policy (30.01.2018.) 
Međimursko veleučilište u Čakovcu (2018). Održivi razvoj. URL: https://www.mev.hr/ index.php/odrzivi-razvoj/ (26.02.2018.)

Ministarstvo rada i mirovinskog sustava (2016). Anketa o standardu zanimanja. Upitnik za poslodavce 2016. godine. URL: http://www.mrms.hr/wp-content/uploads/2016/11/Prilog-4-Anketa-o-standardu-zanimanja-2016.pdf (21.05. 2018.)

Ministarstvo znanosti i obrazovanja (2017). Nacionalni kurikulum međupredmetne teme održivi razvoj. Prijedlog nakon javne rasprave. URL: https://mzo.hr/sites/ default/files/dokumenti/2017/OBRAZOVANJE/NACION-KURIK/MEDUPREDMETNE-TEME/medupredmetna_tema_odrzivi_razvoj.pdf (21.02.2018.)

ODRAZ - Održivi razvoj zajednice (2018). Predmet „Održivi razvoj“ na Metalurškom fakultetu Sveučilišta u Zagrebu. URL: http://www.odraz.hr/hr/projekti/sviprojekti/predmet-odrzivi-razvoj-na-metalurskom-fakultetu-sveucilista-u-zagrebu (26.02.2018.)

Pramling Samuelsson, I. i Kaga, Y. (ur.) (2008). The contribution of early childhood education to a sustainable society. Pariz: UNESCO. URL: http://unesdoc.unesco. org/images/0015/001593/159355E.pdf (25.01.2018.)

Režić, M. (2017). Uskoro jedinstven studij i na hrvatskim fakultetima. Glas Slavonije. URL: http://glas.hr/335792/23/Uskoro-jedinstven-studij-i-na-hrvatskim-fakultetima (26.02.2018.)

SOAS University of London (2018). MA in Environmental Law and Sustainable Development. URL: https://www.soas.ac.uk/law/programmes/ma/ma-in-environmental-law-and-sustainable-development/ (26.02.2018.)

Sveučilište VERN (2018). Zaštita okoliša i održivi razvoj. URL: http://www.vern.hr/ zastita-okolisa-i-odrzivi-razvoj (26.02.2018.)

UNCED - United Nations Conference on Environment and Development (1992). Agenda 21. United Nations Sustainable Development. Rio de Janerio, 3-14 Lipnja 1992. URL: https://sustainabledevelopment.un.org/content/documents/Agenda21.pdf (01.03.2018.)

UNESCO - The United Nations Educational, Scientific and Cultural Organization (2002). Education for Sustainability - From Rio to Johannesburg: Lessons learnt from a decade of commitment. World Summit on Sustainable Development, Johannesburg, 26 Kolovoza - 4 Rujna 2002. Pariz: UNESCO. URL: http://unesdoc. unesco.org/images/0012/001271/127100e.pdf (24.01.2018.)

UNESCO - The United Nations Educational, Scientific and Cultural Organization (2017). Education for Sustainable Development Goals - Learning objectives. Pariz: UNESCO. URL: http://unesdoc.unesco.org/images/0024/002474/2474444e.pdf (24.01.2018.)

University of Graz (2018). Joint International Master's Programme in Sustainable Development. URL: https://studien.uni-graz.at/en/degree-programmes/joint-international-masters-programme-in-sustainable-development/joint-international-masters-programme-in-sustainable-development/ (26.02.2018.) 
Uppsala University (2018). Master Programme in Sustainable Management 2018/2019. URL: http://www.uu.se/en/admissions/master/selma/program/?pKod=SHF2N\&lasar $=14 / 15$ (26.02.2018.)

Vrbičić, A. (2012). Odgoj i obrazovanje za održivi razvoj (Zelena pedagogija) Sveučilište u Rijeci, Filozofski fakultet. Ekvilibrij - časopis studenata pedagogije Hrvatske, 1(1). URL: http://www.pedagogija.hr/ekvilibrij/odgoj-i-obrazovanje-za-odrzivi-razvoj.html (21.02.2018.)

VŠMOD - Visoka škola međunarodnih odnosa i diplomacije Dag Hammarskjöld (2018) Novi studij - Održivi razvoj i međunarodni odnosi. URL: http://www.diplomacija. $\mathrm{hr} / \mathrm{hr} /$ novosti/novi-studij-odrzivi-razvoj-i-medunarodni-odnosi/ (02.02.2018.) 


\title{
COMPARATIVE ANALYSIS OF EDUCATION FOR SUSTAINABLE DEVELOPMENT AND THE NEED FOR EXPERTS IN SUSTAINABLE DEVELOPMENT IN CROATIA
}

\author{
Anastasya Raditya-Ležaić, Ana-Maria Boromisa and Sanja Tišma
}

\begin{abstract}
Summary
Sustainable development is three-dimensional, consisting of economic, social and environmental dimensions. Economic growth is necessary but it cannot support development by itself. The understanding that the protection of the environment and its sustainable use is as important is slowly making its way into development policies. However, although social issues, especially those related to education, are recognized as one of the three key elements of sustainable development, education for sustainable development is not implemented in Croatia on a more significant scale.

In this paper we first look at the concept of sustainable development. Secondly, we examine the concept of education for sustainable development, first by looking at the recommendations for education for sustainable development given by international organizations, and then by analysing different ways in which they are implemented in different countries and at different levels of education (pre-school, primary and secondary school, higher education). In the third part of the paper we examine the current situation in Croatia. Alongside the analysis of existing programmes and research, we present previously unpublished results of our research on the need of Croatian employers for experts in sustainable development. The results reveal that the employers in Croatia are aware of the need to employ experts for sustainable development.
\end{abstract}

Key words: education for sustainable development, experts in sustainable development, education in Croatia, sustainable development

\section{EIN KOMPARATIVER ÜBERBLICK ÜBER DIE BILDUNG ZUR NACHHALTIGEN ENTWICKLUNG UND DEN BEDARF AN FACHLEUTEN IN KROATIEN}

\author{
Anastasya Raditya-Ležaić, Ana-Maria Boromisa und Sanja Tišma
}

\section{Zusammenfassung}

Die nachhaltige Entwicklung hat drei Dimensionen: Die ökonomische, die soziale und die ökologische. Der Wirtschaftswachstum ist unbedingt nötig, genügt aber nicht allein zur Entwicklung. Die Frage der Erhaltung und der nachhaltigen Nutzung der Umwelt als ein Hebel der Entwicklung wird nach und nach in die Entwicklungspolitik integriert. Obwohl jedoch die Gesellschaftsfragen, insbesondere diejenigen, die die Bildung betreffen, als Schlüsselfaktoren der nachhaltigen Entwicklung gelten, wird die Bildung für nachhaltige Entwicklung in Kroatien nicht systematisch durchgeführt.

In dieser Arbeit wird zuerst ein Überblick über die Entwicklung des Konzepts der nachhaltigen Entwicklung dargestellt. Es folgt eine Darstellung der Bildung für nachhaltige Entwicklung, wobei zuerst die Empfehlungen von internationalen Organisationen für Bildung für nachhaltige Entwicklung dargestellt werden und dann die Durchführungsarten in ausgewählten Ländern auf unterschiedlichen Stufen der Bildung (Vorschul-, Schul- und Hochschulbildung). Der dritte Teil der Arbeit befasst sich mit dem Stand in Kroatien. Wir bringen einen Überblick über die bestehenden Programme und die bisherige Forschung, dazu noch bisher unveröffentlichte Ergebnisse der Forschung über Bedarf der Arbeitgeber in Kroatien an Fachleuten für nachhaltige Entwicklung. Die Befunde zeigen, dass Arbeitgeber in Kroatien den Bedarf an Fachleuten für nachhaltige Entwicklung wahrnehmen.

Schlüsselwörter: Bildung für nachhaltige Entwicklung, Fachleute für nachhaltige Entwicklung, Bildung in Kroatien, nachhaltige Entwicklung 